\title{
МЕТОДОЛОГИЯ АНАЛИЗА СОЦИАЛЬНОГО УПРАВЛЕНИЯ В НОВУЮ ЭПОХУ
}

Состояние международных отношений с началом XXI века качественно изменилось. Функционирование однополярного мира с центром в США стало приводить, с одной стороны, к серьезным срывам в решении глобальных и региональных проблем мироустроения, а с другой стороны, к утверждению новых приоритетных участников в мировой политике как следствие противодействия гегемонии США.

Многие социальные аналитики и специалисты политических макропрогнозов стали высказывать идею о наступлении новой эпохи в международных отношениях (См.: напр. Аннан, 2006; Россия и мир,20086 167-230; Мир вокруг России: 2017, 2007; Народонаселение мира в 2001 году, 2001; Капица, 2008: 111-136; Россия 2015, 1999; Кузык, Яковец, 2004; Роузфилд, 2004). Ее началом считаются 1990-е годы. Возникает процесс глобализации, его экономические, геополитические, социально-демографические, энергетические и иные направления. На арену мировой финансовой, социальной, демографической, промышленной, торговой политики стали выходить новые лидеры - Китай, Индия, Бразилия, Россия и некоторые другие страны. Россия, например, в эти годы стала предпринимать первые попытки прекращения «игры в поддавки» с США и их союзниками в Европе после распада СССР.

Началом новой эпохи, как считают многие аналитики, стало также кардинальное изменение политики США и ЕЭС в отношении России. Были оставлены надежды на превращение России в дружественное для них государство, но без права голоса. В американской и западной социальной и политической риторике термины «неоимпериализм», «авторитарный капитализм» или "деспотический капитализм» стали своеобразными клише негативной оценки внутренней и внешней политики России, Китая и некоторых других «восточных» держав. Они используются и при европейском анализе противодействий России пересмотру результатов Второй мировой войны, ее активности по защите русскоязычного населения в странах Балтии, реализации государственных интересов в Кавказском регионе, защите прав сербов в Косово. Как проявление нового империализма оценивается якобы запоздалое введение Россией рыночных отношений в торговле ее энергоресурсами. Новая эпоха характеризуется переходом США и их союзников, а также ЕС, Советом безопасности и сотрудничества в Европе (СБСЕ) к более гибкой политике «неосдерживания» России, Китая, Индии и других государств-конкурентов, уверенно заявивших о себе в решении мировых проблем. Однако попытки подобного регулирования международных отношений часто сопровождаются возникновением новых конфликтов, реализацией корыстных интересов в ущерб сохранению мира.

Признаками новой эпохи считаются:

1. Усложнение эволюции социальных, экономических, политических, этнических и других мировых процессов, возрастание их непредсказуемости проявления. Глобальные отношения стали больше хаотичными, чем управляемыми и регулируемыми. В мировых отношениях существенно возросла доля общепланетарных и региональных политических и финансовых махинаций и авантюр. Все более существенное воздействие на деятельность государств оказывают теневая экономика и коррупция. Неслучайно поэтому Калашников усматривает, например, основную задачу 
России в том, чтобы «прорваться через глобальную смуту» (Калашников 2007: 845).

2. Наступление эры жесткой, а порой и жестокой, экономической, геополитической, идеологической, социокультурной конкуренции в мировых отношениях. Отмечается, что «парадигма современных международных отношений скорее определяется конкуренцией в самом широком смысле этого понятия, ее предметом, помимо прочего, становятся ценностные ориентиры и модели развития. Новизна ситуации заключается в том, что Запад теряет монополию на процессы глобализации» (Лавров 2007: 10).

3. Снижение интенсивности и результативности противодействий мирового сообщества новым и традиционным глобальным вызовам: распространению оружия массового уничтожения, деградации окружающей среды, исламскому экстремизму, коррупции, актуальным и негативным демографическим процессам, сохранению низкого уровня жизни и бедности населения и др.

4. Опасное возрастание реомилитаризации международных отношений. Быстрое перераспределение мест государств-лидеров в мировой политике и их влияний на принятие решений актуализировало проблему силового утверждения новых субъектов геополитики и такого же силового противодействия традиционных лидеров с целью сохранения своего лидерства.

5. Признаком новой эпохи признаются затруднения в поиске более эффективных путей социокультурного развития каждой страной, а также путей сохранения мира на планете, создания равноправных взаимозависимых и взаимно-дополняемых международных связей в сферах финансовой деятельности, экономики, энергоресурсов, гражданского общества, материальной и духовной культуры, уровня и качества жизни человека.
Эти и другие признаки наступления не только нового века, но и новой эпохи требуют их внимательного исследования. Во-первых, актуализируется задача разработки среднесрочных и на более отдаленную перспективу прогнозов и сценариев развития планетарной цивилизации, регионов и отдельных стран. Вовторых, глубокое изучение новой эпохи необходимо для определения практических мер и действий по сдерживанию нового витка гонки вооружений, для сохранения условий нераспространения оружия массового уничтожения. На этой основе, как представляется, только и можно разрабатывать оптимистические модели сохранения мира на планете и решения глобальных проблем. В-третьих, изучение особенностей новой эпохи имеет первостепенное значение для регулирования системы международных и межгосударственных отношений, коренной реконструкции социального управления странами и регионами, социальными процессами в России.

В социально-гуманитарных науках сегодня сложилось несколько подходов к определению социального управления. Важно обратить внимание на два из них, которые ориентированы на объяснение управления всем обществом (социальное управление в широком смысле) и на управление социальной сферой жизни общества (социальное управление в узком смысле). Но всякое понимание социального управления нацелено на упорядочивание отношений и взаимодействий между людьми.

В общем плане социальное управление можно определить как целенаправленное воздействие на общественные процессы, осуществляемое посредством специальных органов и организаций, предназначенных совершенствовать целостность и структуру социальной системы, ее оптимальное функционирование и развитие в интересах государства, конкретных субъектов и всех граждан. 
Объектом управления является социальная система, в качестве которой могут выступать социальные общности и их институты, уровни и сферы жизни общества, отношения и взаимодействия людей в материальной и духовной культуре, в институциональных культурах и субкультурах. Одним из основных объектов социального управления всегда оставались граждане страны, их уровень и качество жизни. Социальными системами могут быть представлены также общества в рамках государственной организации, сообщества и все планетарное общество. Признаками системности обладают многие другие относительно самостоятельные общественные образования и структуры. К их функционированию и развитию применимо понятие «социальное управление».

Социальное управление проявляет себя одной из необходимых функций жизнедеятельности сложных и динамических общественных систем. Благодаря ее реализации обеспечивается сохранение существенных признаков, элементов структуры и закономерностей социальной системы, поддержание стабильного существования или перевод в другое качественное состояние с программой, обусловленной новыми обстоятельствами, задачами и целями жизнедеятельности людей.

Само социальное управление, как и управляемая социальная система, имеет свою структуру. Ее основными типовыми элементами считаются:

- выявление проблемы и анализ проблемной ситуации;

- изучение субъекта и объекта управления;

- постановка целей управления;

- проработка желаемых вариантов решения проблемы и достижения поставленных целей;

- выбор средств и методов реализации управления;
- разработка стратегии оптимального достижения результатов и осуществление прогнозирования;

- принятие решения;

- организация выполнения решения;

- контроль за ходом выполнения решения и всего процесса управления, внесение необходимых корректив.

Анализ социального управления в современном обществе основывается на изучении социологических аспектов процесса управления. Отношения различных субъектов в основных сферах и видах жизнедеятельности общества и сообществ приобретают конкретное наполнение в ходе выявления и сравнения их интересов и потребностей, понимания смысла жизни, целей и идеалов, способов и средств их достижения, планов и программ жизнедеятельности. Привлечение динамики социологических показателей повышает достоверность анализа. Хотя иногда она оказывается конъюнктурной, когда реализуется какой-либо социальный заказ или проявляется некомпетентность, субъективизм автора социологических измерений.

Процесс управления в обществе важно соотносить с таким качеством социальной системы (объекта управления) как управляемость. Ее можно определить такой способностью системы, которая проявляется в сохранении ее стабильности и поступательного развития, в предотвращении кризисов и конфликтов, обеспечении безопасности участников системы, оптимальном контроле отношений и процессов системы. Управляемость социальной системы может быть высокой, средней или низкой. Уровень управляемости зависит от трех групп показателей.

Первую группу составляют показатели субъектов и объектов управления: их число, иерархия, наличие у субъектов управления профессиональных качеств, готовность объектов управления принимать и исполнять управленческие решения и др. Вторую группу образуют 
деятельностные показатели: адекватность управления планам и целям развития социальной системы, существующим вызовам и угрозам, сложившимся условиям, а также взаимная дополняемость действий субъектов управления, их легитимность и легальность, совпадение с позитивными государственными и общественными интересами, общими интересами граждан. Третья группа показателей включает принципы, нормы, законы, режимы и институты, с помощью которых осуществляется управление социальной системой.

Теоретическая характеристика структуры и показателей управляемости социальной системы немыслима без привлечения конкретных социологических данных и статистики. В применении к социальному управлению в условиях новой эпохи названные элементы структуры и показатели социальной системы имеют существенную специфику и содержание.

Методологический анализ современного социального управления будет рассмотрен на особенностях проявления новой эпохи в жизнедеятельности мирового сообщества и российского общества. Какие сферы социального управления в России и мировом сообществе актуальны сегодня и будут сохранять значимость в новую эпоху? Важно, прежде всего, обратить внимание на проблемы регулирования отношений между государствами и другими субъектами мирового сообщества в сферах финансовой и производственной деятельности, политики и военной политики, социальной демографии, торговли, энергетических ресурсов, новых технологий и информации, экологии, глобальных и региональных угроз, уровня и качества жизни человека, проблем будущего.

Казалось бы, эти проблемы характеризуют состояние мировой цивилизации, международных отношений. Какое отношение к ним имеет Россия? Как эти проблемы соотносятся с социальным управлением? Пояснения вряд ли необходимы, учитывая все возрастающее воздейст- вие на каждое государство процессов интеграции и глобализации. Но возникают новые проблемы: как сохранить в таких условиях самостоятельность государства и народа, цивилизационную идентичность и национальную культуру, обеспечить безопасность страны, общества и личности?

Управление отношениями субъектов внутри страны, взаимодействием или противодействием международных субъектов в условиях новой эпохи кардинально актуализируют проблему социального управления внутри российского государства и вне его. Учитывая снижение активности и результативности управленческих действий международных и региональных институтов (ООН, ЕС, ШОС, «Большая восьмерка» и др.), международные отношения перешли, как считается, в фазу регулирования. Оно замещает управление как деятельность менеджментных надгосударственных институтов. Государственные и негосударственные субъекты мировых отношений вынуждены заменять управление межсубъектным регулированием. При этом на первые позиции выдвигается регулирование международных и региональных связей со стороны негосударственных субъектов, что дополнительно актуализирует социологический анализ такого регулирования.

Возрастание доминирования негосударственных субъектов в регулировании мировых отношений и процессов усиливает хаотичность и непредсказуемость существования мирового сообщества, регионов и каждой отдельной страны. Главным новшеством новой эпохи признается формирование целостного и взаимосвязанного мира. Но оно пока «обеспечивается во многом сетевыми средствами, хаотическим переплетением множества взаимодействий» (Суслов 2008:144).Снижается эффективность внутригосударственного управления, государственного и межгосударственного регулирования, а также общемирового управления со стороны офи- 
циальных международных и региональных институтов.

Хаотичность международных отношений и неконтролируемость процессов бросают вызов всей системе международного управления и регулирования, а особенно ее главному элементу - государству (Суслов 2008: 148-160). Конечно, многие негосударственные субъекты действуют не только в своих интересах, но и на благо государства. До недавнего времени считалось, что такая позитивная деятельность характерна только или преимущественно для развитых, вроде бы как цивилизованных, государств. Но такие выводы часто оказываются ошибочными. Так, глобальный финансовый кризис второй половины 2008 года показал корыстные интересы и несостоятельность основных американских негосударственных банков и объединений, скрытое, но действительное их противодействие государственным интересам США в сфере финансовой политики.

Примеры подобных «цивилизованных» фальсификаций и обмана показывало само правительство США. Например, в августе 1971 года оно отказалось выполнять обязательства по конвертированию долларов в золото по фиксированной цене. Фактической причиной отказа и наступившего затем кризиса стали злоупотребления статусом эмитента главной международной валюты, особенно в условиях войны США во Вьетнаме. Согласованный сброс долларов, который готовили в 1970 году ведущие страны Западной Европы, не состоялся (Буторина, 2008: 86). Регулирование финансовых отношений между государствами и негосударственными субъектами тогда и сегодня существенно дестабилизировало их отношения, снизило показатели управляемости финансовыми потоками и эффективность социального управления.

Ослабление управленческих и регулятивных функций со стороны государств и их международных организаций усиливает не только хаотичность и непредсказуемость течения мировых процессов и внутригосударственных отношений. Оно повышает стремление самих государств решать свои проблемы с использованием силы, учитывая несостоятельность мирового сообщества наказывать за такие действия. Особенно это характерно для современной военной политики США.

Показателем новой эпохи стало утверждение однополярного мира. США сегодня претендуют на гегемонию не только регулирования международных отношений, но и на статус единого центра управления государственными и негосударственными взаимодействиями мировых субъектов. Вне изучения сложившегося положения невозможно понять и осмыслить состояние и перспективы социального управления в конкретном государстве, в том числе и в России.

В теоретическом анализе современных международных и региональных связей как-то само собой разумеющимся утвердилось положение о необходимом (не добровольном) приведении всех стран и народов к единым нормам и принципам жизнедеятельности. Создается впечатление, что «правильно» мыслить и поступать могут только руководители развитых стран. Образцом этих норм и принципов якобы являются «цивилизационные» модели американской демократии, предпринимательства, гражданского общества, индивидуализма и свободы человека, общества массового потребления. В качестве исходных предлагаются также американские методики определения современных вызовов и угроз, способов противоборства с ними. На деле оказывается, что вызовы и угрозы существуют только в отношении евроатлантической цивилизации. Все другие народы и государства только и мечтают якобы о том, чтобы «насолить» культурным американцам и их друзьям-европейцам.

В разработке теории международного регулирования и социального управления остают- 
ся в тени или совсем не обсуждаются вопросы сохранения идентичности национальных и региональных культур, интересы народов самим определять перспективы и направления своего развития. В свое время социальное управление в Советском Союзе подвергалось критике со стороны западных идеологов за нивелирование личности. Теперь данное нивелирование по отношению к «нецивилизованным» обществам насаждается извне со стороны США и евроатлантической «цивилизации». Термин «цивилизация» заключен в кавычки потому, что так цивилизованные государства и их правительства не должны поступать.

Почему, например, народы Африки, Латинской Америки или так называемого «расширенного» Ближнего Востока с необходимостью и под давлением должны перестраивать свою жизнедеятельность по американским образцам? А если они этого не желают? Если они хотят сохранить, пусть и отсталую по современным оценкам, но свою традиционную культуру, родоплеменные или феодальные отношения? Наверно они имеют на это право. В ином случае французская демократия, например, должна стать американской демократией, а американские формы религиозности должны заменить все иные конфессиональные формы. Возможно, в этих рассуждениях прозвучали крайности. Но они созвучны с теми крайностями однополярного мира, когда все угрозы в мире оцениваются угрозами только евроатлантической цивилизации, а ее стандарты и признаки произвольно трактуются общечеловеческими.

Часто насильственное насаждение норм, принципов и ценностей «цивилизованных» стран другим странам и регионам объясняется на Западе и в США необходимостью устранения угроз со стороны «отсталых» государств евроатлантической цивилизации. Отсталые народы и государства якобы не могут жить и развиваться, не угрожая западному миру. Конечно, существуют, например, международный терро- ризм, исламский экстремизм, сепаратизм или национализм. Но угрозы такого характера составляют опасность не только для Европы или США. Важно добавить и то, что международный терроризм не имеет ярко выраженного религиозного или национального лица. В самих США достаточно «ястребов» и авантюристов всех мастей, которые способны на террористические действия. Свидетельством тому являются авантюры во Вьетнаме и Ираке, бомбежка объектов в Югославии (1999) и Сомали (2006), расследования гибели южнокорейского пассажирского самолета на Дальнем Востоке (1983) и террористического акта в самих США (2001), многие другие примеры.

Более актуальным с точки зрения международного регулирования и социального управления (управления огромными массами людей в десятках стран) является теоретический анализ двух мировых войн XX века. Кто их начинал и вел, кто угрожал «цивилизованной» Европе и США, как не сами участники этих войн? Россия односторонне вышла из Первой мировой войны с огромными для себя потерями, не дождавшись нескольких месяцев до ее окончания и победы в ней. Советский Союз был насильственно втянут во Вторую мировую войну и одержал победу всемирно-исторического значения, осуществив основной вклад в сокрушительный разгром «цивилизованного» (то есть зародившегося в западной «образцовой» цивилизации) фашизма.

Откуда возникли обе мировые войны? Из отсталой Африки или «деспотического» Востока? Они возникли из «цивилизованной» Европы. Во имя какой демократии и какого мироустроения погибли десятки миллионов людей? После этих варварских и истребительных войн ни Европа, ни США уже не имеют права считать себя цивилизованными. На насильственный характер международного регулирования со стороны европейской цивилизации указывали не только российские, но и многие зарубежные 
исследователи. И сегодня стремление американского руководства как «гегемона» международного регулирования и социального управления решать проблемы планетарного общества силовыми методами не исчезло.

Особенно трагически выглядит в новую эпоху ослабление норм и правил поведения государств. По количеству и охвату сфер регулирования международных отношений число норм и правил за последние 15-20 лет существенно увеличилось (Аннан, 2006: 167-230; Московско-Шанхайская модель, 2006: 41-99; 2008: 77-110. ). Но наиболее значимые нормы в системе международного регулирования и повышения управляемости его участников все более игнорируются или разрушаются. Новой «нормой» становится ситуация, когда в инициативном порядке со стороны того или иного государства предлагаются решения, противоречащие уже существующим или подменяют их. Например, многие силовые решения США в разных регионах мира поставили под сомнение действие таких норм, как легальность и легитИМность.

Все более утверждается норма принятия силовых решений не столько через Совет безопасности ООН, сколько региональными организациями коллективной безопасности. США, например, открыто оспаривают сегодня монополию Совета безопасности ООН на силовые решения. Американское руководство стремится наделить НАТО некими общеевропейскими или даже общемировыми полномочиями «миротворчества» из-за того, что такие полномочия ООН якобы ослабли или стали неэффективными.

В 1990-е годы введена силовая норма «гуманитарной интервенции». Она активно используется США и НАТО для прикрытия корыстных целей замены неугодных политических режимов, импорта в ту или иную страну «цветных революций», утверждения своего влияния над энергоресурсами или политикой в регионе.
Поэтому «гуманитарная интервенция» не пользуется всеобщей поддержкой. США явочным порядком приняли доктрину «упреждающих ударов» (на деле - превентивных войн), которая противоречит миротворческим решениям ООН. Как ни странно, сегодня отсутствует универсальное для ООН определение международного терроризма, что затрудняет консолидацию мирового сообщества в борьбе с ним. Так называемые "двойные стандарты» в оценке терроризма часто исключают принятие эффективных и своевременных решений Советом безопасности ООН, разъединяют государства.

Дестабилизирована сегодня и норма государственного суверенитета. Его определение как ответственность государства перед населением и способность государства выполнять свои базовые функции (Суслов 2008: 163). исключает такие существенные признаки суверенитета, как целостность и независимость государства, нерушимость и неприкосновенность его границ, использование природных и социальных ресурсов, самостоятельность осуществления внутренней и внешней политики. Наличие именно этих показателей, как считают многие исследователи, обеспечит сохранение России и российской цивилизации как единицы человеческой истории (Русская доктрина 2007: 771839; Абрамян 2007:232-260).

Важнейшей сферой международного государственного регулирования и внутригосударственного управления остается нераспространение оружия массового уничтожения (ОМУ) и его непроизводство в неядерных странах. Речь идет не только о ракетно-ядерном и термоядерном оружии, но и других видах ОМУ. Многие политики и специалисты в этой сфере считают, что сегодня механизм сдерживания размыт и требуются новые усилия со стороны ООН и региональных организаций коллективной безопасности, а также от России и США по разработке современных правовых норм нераспространения ОМУ. Решение этой проблемы непос- 
редственно связано с социальным управлением внутри конкретного государства, так как ОМУ составляет угрозу жизни прежде всего гражданам государства, а его производство воздействует на снижение уровня и качества жизни.

Из выше сказанного следует, что совершенствование социального управления и его социологической составляющей в мировом сообществе во многом обусловлено особенностями новой эпохи, изменившейся ролью России в регулировании международных отношений. Оно зависит, конечно, и от состояния внутренней управляемости российского общества.

Во внутреннем функционировании российского общества на первые позиции выдвинулся вопрос усиления государственного социального (в широком смысле) управления. Кто сегодня еще выступает за “уход» государства от управления экономикой или сферой духовной жизни, тот просто лукавит или выполняет какойлибо социально-политический заказ. Сегодня становится все более очевидным, что рыночные отношения в российской экономике или, например, в сфере искусства, не отвечают основному рыночному принципу - адекватности спроса и предложения. Они не выводят Россию на передовые рубежи экономического, технического и социокультурного развития.

Негосударственные субъекты России монополизировали многие важные сферы финансовой, производственной, торговой деятельности, сервиса. Они специально и целенаправленно инициируют спрос на те или иные виды товаров и услуг в своих корпоративных, а также и корыстных интересах. Интересы граждан России удовлетворяются избирательно и с нарушением норм гражданственности, гуманизма и справедливости. Не случайной стала, возможно, разработка государственных национальных проектов и программ для сельского хозяйства, жилищного строительства, образования и медицинского обслуживания, демографического процесса. Рыночный подход к регулированию, функционированию и развитию этих сфер пока оказался несостоятельным.

Сказанное не означает, что негосударственные субъекты в социальных связях и отношениях проявляют себя или оцениваются только негативно. Но их активность все-таки локальна и корпоративна. Она не может охватить всю систему управления или хотя бы регулирования социальных отношений в российском обществе. Негосударственные субъекты и не предназначены для реализации таких функций. Полномочиями управления российским обществом в масштабе страны наделены органы (институты) государственной власти. Поэтому государственное социальное управление в Российской Федерации и государственное правовое регулирование отношений субъектов в основных сферах жизни нашего общества и первичных социальных институтах должно быть основным и эффективным.

Не проявил себя рыночный подход и в основной, «родной» для рынка, сфере финансовой деятельности и промышленного производства, создании новых технологий и форм социальной организации. Прогнозы показывают, что доля России в мировом валовом продукте (МВП) к 2020 году не поднимется выше 2,3-2,5 \%. А если темпы роста окажутся меньше 8-11\% в год, то доля России в ВНП будет сокращаться. Например, промышленность России поставила в 2008 году антирекорд. В ноябре оно сократилось на 8,7\%, а в декабре падение составил 19\% при общем приросте за год на 22,5\%. Парадоксы рыночного хозяйствования и управления деятельностью его субъектов поразительны и в сельском хозяйстве. Стоимость зерна, например, в 2008 году подешевела в 22,5 раза, а цены на хлеб увеличились в целом на 25\%. Объяснить такое «расхождение» гражданам России трудно, если не лукавить или скрывать несовершенство государственного ре- 
гулирования не столько в деревне, сколько в городе.

Рыночный принцип хозяйствования у нас реализуется уже около 20 лет. Результат плачевный и обидный для такого государства как Россия. Можно сравнить: индустриализация страны на рубеже 20-30-х годов XX века под государственным руководством на значительно большей территории, чем современная Россия, в условиях международной изоляции и сложной экономической ситуации внутри страны была осуществлена с грандиозными для того времени результатами всего за несколько лет.

Можно привести совсем новый пример неэффективного социального регулирования и неспособности частного сектора развивать производственную сферу, прямо связанную с уровнем и качеством жизни российских граждан. Известно, что в условиях разразившегося финансового кризиса правительство России решило оказать основным отечественным банкам государственную поддержку в несколько триллионов рублей для стимулирования кредитной системы и производства на местах. Известно также, что от 50 до 70 процентов этих средств банки потратили на погашение своих долгов перед зарубежными банками, а от 28 до 45 процентов государственных субсидий перевели в доллары. До непосредственных производителей, для которых и предназначалась государственная антикризисная финансовая поддержка, дошло всего около 2\%. Налицо реализация банками частного сектора своих корыстных интересов и полное игнорирование интересов производителей и всех российских граждан.

Между тем, в экономике, науке, образовании и других сферах отношений многих и разнообразных субъектов пока не произошло радикальных преобразований и прорывов, прежде всего, из-за недостатка финансовых средств. Указ президента РФ от 2002 года о создании национальной инновационной системы до сих пор не выполнен. Если к концу 1970-х годов на долю СССР приходилось до половины мировых открытий и изобретений, то сегодня доля «новой экономики Росси» только внутри страны составляет всего 3-7\%. Из 50 базовых технологий мира СССР лидировал в 32, а сейчас только в 8-ми. По заниженным, как считается, данным сегодня около 10 тыс. живущих в России ученых трудятся на американские фирмы и корпорации, а около 20 тыс. - на европейские (Рубанов 2015: 217-223.).

Повысить эффективность государственного регулирования отношений российских субъектов в сфере экономики, как отмечается во многих публикациях, предпочтительно в трех основных направлениях: а) денационализация (разгосударствление) тех объектов экономики, которые в условиях государственной собственности не демонстрируют рентабельность и консервативны к инновациям, но востребованы субъектами частной и иных форм негосударственной собственности при сохранении трудовой занятости; б) возвращение в государственную собственность важных для страны или региона объектов экономики, сохранение стратегических объектов промышленности и других сфер хозяйствования в государственной собственности, подготовка для них современных профессиональных кадров, кардинальное обновление содержания их деятельности в новых условиях; в) повышение эффективности государственных воздействий на существующие объекты и сети частного сектора экономики.

Современное социальное регулирование, а также и управление отношениями субъектов в экономической деятельности со стороны ветвей власти Российского государства - важнейшая проблема открытого и непредвзятого исследования отечественной науки. Ее решение для XX1 века с необходимостью должно быть соотнесено с двумя исходными социальными показателями экономической жизни - государственность (державность) и народность (гражданственность). 
Главные параметры именно русской, но не западной модели экономики, отмечает, например, О.А.Платонов, определяющие хозяйственный и трудовой менталитет русских людей, должны быть положены в основу при разработке любых экономических мероприятий, особенно трудовой демократии и трудовой мотивации (Платонов 2008: 781). Такими параметрами и выступают государственность и народность. Им должны соответствовать условия и организация экономической жизни в современном российском обществе и на перспективу, социальное управление экономическими отношениями и регулирование деятельности субъектов.

Усиление государственной составляющей в социальном управлении необходимо и в сфере национальных и демографических отношений. За годы нового века удалось решить ряд проблем. Так, уменьшение субъектов Российской Федерации с 89 до 83 осуществлено в основном за счет включения (возвращения) ряда национальных образований в областные и краевые субъекты. Были восстановлены традиции и хозяйственные связи, сложившиеся за предыдущие столетия. Повысились возможности решить вопросы занятости населения, образования, повышения качества жизни национальных меньшинств. В основном стабилизировалась обстановка в национальных образованиях России на Кавказе. Но проблемы в области качества жизни и трудовой занятости национальных общностей, которых в России более 170, остались и требуют новых решений.

Реализация национального проекта В сфере решения демографической проблемы также имеет положительные результаты, показывает преимущества государственного социального управления. Но она обусловлена многими другими факторами и показателями, в том числе и внешними для России. Внутреннее социально-демографическое государственное уп- равление все теснее оказывается связано с состоянием мировых демографических процессов.

Показательным в этом плане является радикальное изменение миграционных процессов. До 1970-х годов основные миграционные процессы не имели ярко выраженной направленности, хотя многие из них были связаны с Европой и Америкой. Сегодня массовая миграция направлена с Юга на Север, в том числе и в Россию. Резко возросла численность мигрантов. За период с 1990 по 2005 годы мировая миграция выросла на 36 млн. Считается, что за первую половину XXI века в развитые страны переместится около 120 млн. Основа миграции - низкий уровень жизни, социальная напряженность и трудности найти работу в своей стране. Россия оказалась одной из основных приоритетных стран для трудовых мигрантов. Основная их часть - из бывших республик СССР, а сегодня стран СНГ.

В странах «Севера» Россия по количеству населения находится на втором месте (142 млн.) после США (306 млн. - 2007 г.). Ее собственные трудовые ресурсы ограничены, учитывая и большие территории. Поэтому она располагает значительным ресурсом занятости. Приоритетность России для мигрантов из стран СНГ определяется также прошлыми связями и традициями, установившимися между народами Советского Союза, особенно после Великой Отечественной войны 1941-1945 годов. Способствует миграции и знание многими ее представителями русского языка. Много мигрантов приезжает из Китая, Северной Кореи и других стран.

В таких условиях социальное регулирование демографических процессов со стороны институтов власти России существенно осложнилось. Общественное мнение российских граждан в отношении мигрантов противоречивое, но больше негативное из-за криминальной характеристики приезжих. Около половины правонарушений и преступлений совершаются 
сегодня в России мигрантами. Многие «гастарбайтеры», получив официальную регистрацию, не стремятся найти работу, становятся объектом криминальных структур. Значительное число мигрантов пересекают российскую границу нелегально, что также не способствует формированию положительного общественного мнения.

Решение российского правительства наполовину сократить число мигрантов в 2015 году отражает стремление государства упорядочить и сделать подконтрольным приток трудовых ресурсов из-за рубежа. Социальный смысл государственного регулирования трудового рынка состоит в обеспечении достойного уровня и качества жизни российских граждан, а также создания необходимых жилищно-бытовых, экономических и социально-культурных условий для мигрантов. По данным ВЦИОМа, сегодня 42\% российских граждан считают, что их права и

\section{ЦИТИРОВАННАЯ И УПОМЯНУТАЯ ЛИТЕРАТУРА}

1. Абрамян, Е. (2007) Судьба цивилизации. Что нас ожидает в XX1 веке? М.: ИНФРА-М.

2. Буторина, О.(2008) Мировые финансы к 2020 году // Россия и мир. Новая эпоха. 12 лет, которые могут все изменить. М.: АСТ: РусьОлимп.

3. Калашников, М. (2007) Русский шанс XXI века: прорваться сквозь глобальную смуту // Русская доктрина. М.: Яуза-пресс.

4. Капица, С. (2008) Очерк теории роста человечества. Демографическая революция и информационное общество // Безопасность Евразии. № 1(31).

5. Аннан, К. (2006) Доклад Генерального секретаря о работе Организации. 16 августа 2006 года // Безопасность Евразии. № 4(26).

6. Кузык, Б. Яковец, Ю. (2004) Россия - 2050: стратегия инновационного прорыва. М.: ЗАО «Издательство «Экономика». интересы на предприятии никто не защищает. А 30\% граждан отмечают возможность массовых выступлений против падения уровня жизни. Трудовые права и интересы мигрантов защищаются больше неудовлетворительно, чем удовлетворительно.

Таким образом, особенности социального управления и регулирования в мировом сообществе, в России в том числе, обусловлены спецификой новой эпохи. Сегодня российское общество и государство более многообразно включены в систему мировых социальных связей. Для России главным направлением совершенствования внутреннего социального управления становится усиление государственного участия в упорядочивании отношений субъектов в сфере финансово-экономической деятельности, повышения качества жизни российских граждан.

7. Лавров, С. (2007) Настоящее и будущее глобальной политики. Взгляд из Москвы // Россия в глобальной политике. Т. 5. - № 2.

8. Мир вокруг России: 2017. Контуры недалекого будущего (2007). М. : Культурная революция.

9. Московско-Шанхайская модель миропорядка XX1 века (2008) // Безопасность Евразии. 2006. - № 4; 2008. - № 1.

10.Народонаселение мира в 2001 году. Этапы и вехи: население и экологические изменения. М.: Культурная революция.

11.Оганян, К., Оганян, К.(2013) Социальный идеал и выбор оптимального пути глобализации. Global crisis of contemporaniety in the sphere of mindset? Social values and political interests correlation. Materials digest of the XXXV International Research and Practice Conference and the III stage of the Championship in political, philosophial and military sciences. (London, November 05 - November 12, 2012). London.

12. Оганян, К., Бранский, В., Оганян, К. (2014). 
Глобализация и общечеловеческая ценность. Журнал: Гуманитарий Юга России. №4.

13. Платонов, О. (2008) Экономика русской цивилизации. М.:Институт русской цивилизации Россия - 2015: оптимистический сценарий. М.: ММВБ, 1999.

14. Россия и мир (2008). Новая эпоха. 12 лет, которые могут все изменить. М.: АСТ: РусьОлимп.

15. Роузфилд, С. (2004) Сравнительная экономика стран мира: культура, богатство и власть в XXI веке. - М.: МГИМО(У).
16. Рубанов, А. (2015) Новые технологии // Россия и мир. Новая эпоха... М.: ВШЭ.

17. Русская доктрина (2007) (Сергиевский проект). - М.: ММВБ.

18. Афанасенко, И. (20014) История русской цивилизации. - В 3 кн. - Кн. 2. СПб.: Питер.

19. Стратегический ответ России на вызовы нового века (2004). М. изд-во «Экзамен».

20. Суслов, Д. (2008) Можно ли управлять миром // Россия и мир. Новая эпоха. 12 лет, которые могут все изменить. М.: АСТ: Русь-Олимп.

Каджик ОГАНЯН

\section{МЕТОДОЛОГИЯ АНАЛИЗА СОЦИАЛЬНОГО УПРАВЛЕНИЯ В НОВУЮ ЭПОХУ}

\section{PEЗЮME}

Исследования социального регулирования и управления отношениями субъектов в экономической деятельности со стороны ветвей власти Российского государства - важнейшая проблема открытого и не предвзятого исследования отечественной науки.

Методологический анализ современного социального управления рассмотрен на особенностях проявления новой эпохи в жизнедеятельности мирового сообщества и российского общества. Исследуются проблемы регулирования отношений между государствами и другими субъектами мирового сообщества в сферах финансовой и производственной деятельности, социальной демографии, торговли, энергетических ресурсов, глобальных и региональных угроз, уровня и качества жизни человека, проблем будущего. Дается обоснование того как сохранить в таких условиях самостоятельность государства и народа, цивилизационную идентичность и национальную культуру, обеспечить безопасность страны, общества и личности.
Аргументировано, что совершенствование социального управления и его социологической составляющей в мировом сообществе во многом обусловлено особенностями новой эпохи, изменившейся ролью России в регулировании международных отношений. Оно зависит, конечно, и от состояния внутренней управляемости российского общества. Для России главным направлением совершенствования внутреннего социального управления становится усиление государственного участия в упорядочивании отношений субъектов в сфере финансово-экономической деятельности, повышения качества жизни российских граждан.

Ключевые понятия: глобализация, признаки новой эпохи, социальное управление, показатели управляемости, типовые элементы социальной системы, хаотичность международных отношений, идентичность национальных и региональных культур, международный терроризм, легальность, легитимность, «гуманитарная интервенция», «двойные стандарты», 


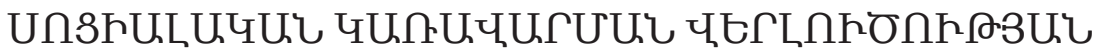

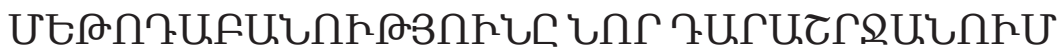

\section{UUథกФПЋU}

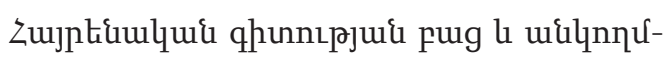
aulquil htinuqnunnıpjuis hưưu quplenpu-

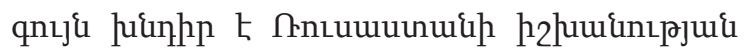

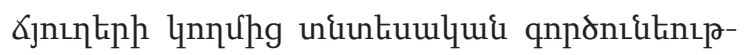
juid utig unıptiluniteph hupuptennıpjnequteph

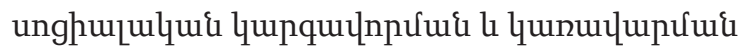
htinuqnunnıpjnı\&ilipn:

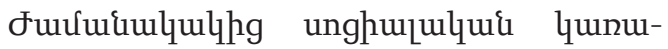

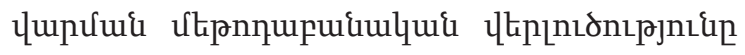

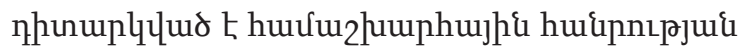

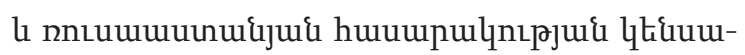

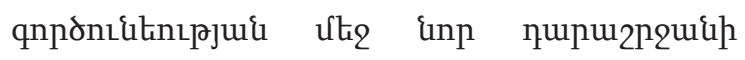

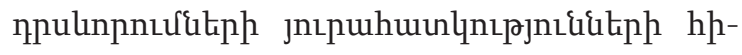

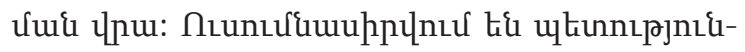

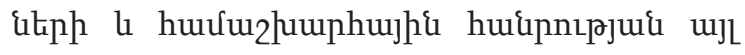
unıptilunitiph uhql hupuptipnıpjnequteph

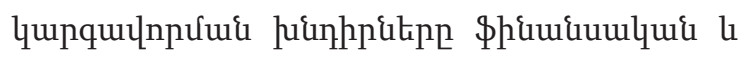

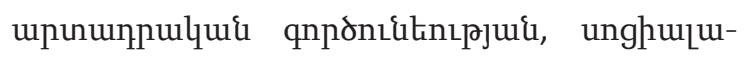

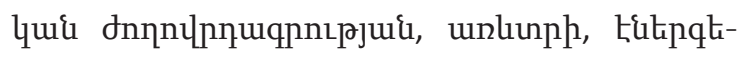
unpluiluis ntunsputitph, qlnpur le unupu-

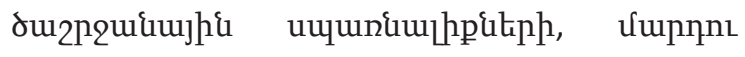
ljuiph dulumpulh la npulh, wumqujh

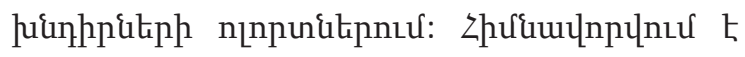

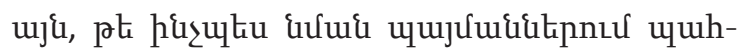

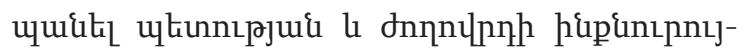

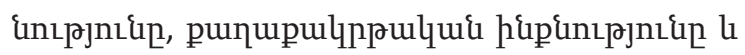

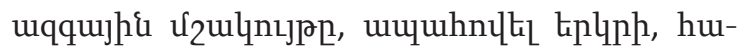

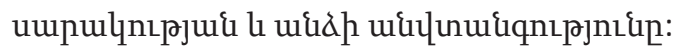

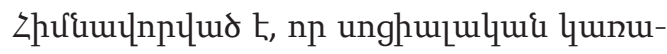

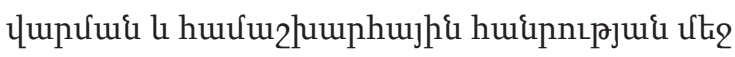

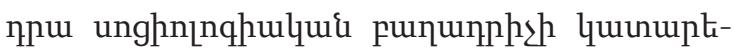

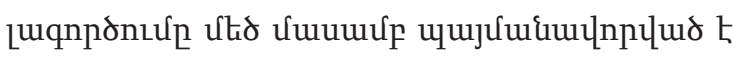

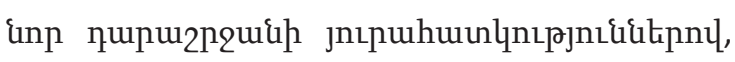

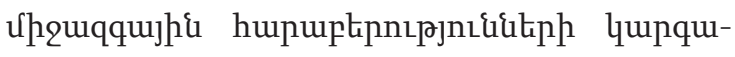

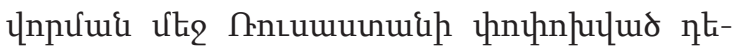

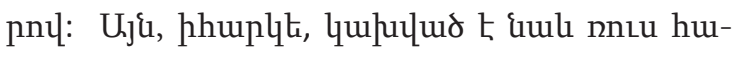

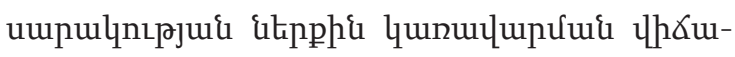

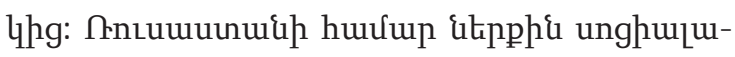

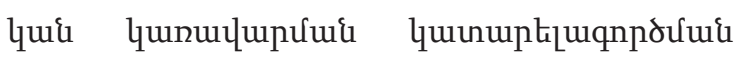

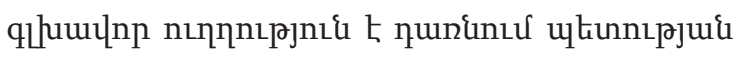

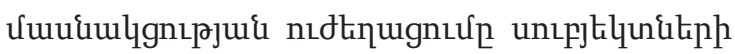

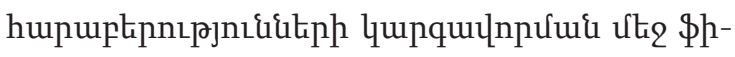

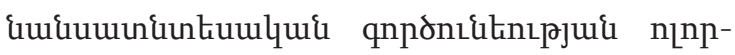
unnuर, nntuwuunuip punupughitiph ljuiph npulı̆ pupànugưưư utı:

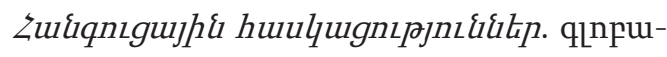
jugntu, inn nupurnquip hujunuip2ulip, un-

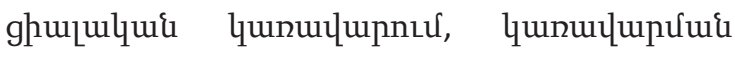

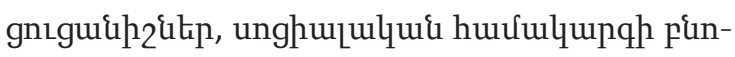
pn2 unuppte, uhquqqujhi hupuptennıpjnı\&-

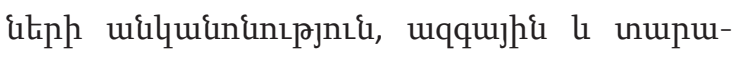

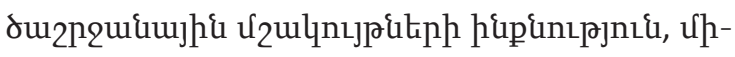

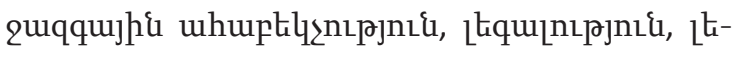

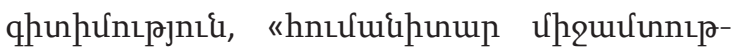

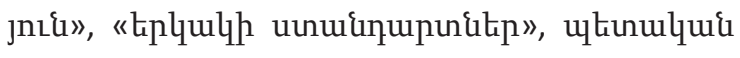

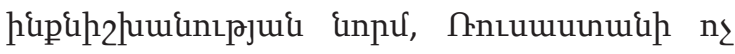


ukinulquis untpjtiluniten, Uhqpughnd le dn-

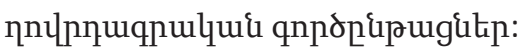

Kadzhik OHANYAN

\title{
METHODOLOGY OF SOCIAL MANAGEMENT ANALISYS IN THE NEW AGE
}

\begin{abstract}
The most important problem of open and impartial investigation of Russian science is the study of social regulation and control of the relations of subjects in economic activity from the branches of the Russian state. Methodological analysis of the current social management features are considered at the manifestation of a new era in the life of the world community and the Russian society. The problems of relations regulation between states and other actors of the international community in the areas of financial and operating performance, social demography, trade, energy resources, global and regional threats, the level and quality of human life, the problems of the future are investigated. Are given grounds for retaining in these terms the autonomy of the state and nation, the civilizational identity and national

course, also on the state of the internal handling of the Russian society. The main focus of the internal improvement of social management, for Russia, is becoming increasing state involvement in ordering subjects relations in the field of financial and economic activities, improving the quality of Russian citizens' life.

Key concepts: globalization, signs of a new era, social management, performance handling, typical elements of the social system, the randomness of international relations, the identity of national and regional cultures, international terrorism, legality, legitimacy, "humanitarian intervention", "double standards", the rate of national sovereignty, non-state actors in Russia, migration and demographic processes.
\end{abstract} culture, for ensuring the security of the country, society and the individual.

It is argued that the improvement of social governance and its sociological component in the international community is largely due to the peculiarities of the new era, the changing role of Russia in regulating international relations. It depends, of 